\title{
A Study of Tribal Composition and Conflict in Darfur
}

\author{
Gao Yifei
}

\author{
School of Oriental and African Studies, Guangdong University of Foreign Studies, Guangzhou, Guangdong, 510420, \\ China \\ Email: iamfaye@126.com
}

\begin{abstract}
More than 80 tribes are distributed in the Darfur region of Sudan. The composition of tribes is intricate. Moreover, the production modes are different, which are composed of the Arab involved in the nomadic herding and non-Arab black people engaged in farming. In the early days, the armed conflicts occurred frequently among various tribes mainly arising from contending for the land, livestock, water and other ecological resources. During the colonial period, the Anglo-Ethiopia government executed an "indirect rule" policy on Darfur, which resulted in the disintegration of the traditional tribal governance model, impact of the original beliefs and identities and emergence of racism. What is worse, Chad and Libya intervened in the civil war in Sudan, triggering regional conflicts. In 2003, the Darfur crisis broke out on a full scale, which fell into the most serious humanitarian crisis across the globe. The crisis was formed by the escalation of internal conflicts of different tribes into national political and economic conflicts, and then the "internal conflicts" evolving into international conflicts as well as the excess interference in domestic conflicts of foreign forces. In addition, the disruption of South Sudan on July 9, 2011 had a demonstration effect on the Darfur region. It
\end{abstract} could become another South Sudan.

Keywords: Sudan, Darfur crisis, Tribes

\section{Tribal Composition with Intricate Structure}

Located in the western region of Sudan, the administrative area of Darfur Plains is divided into five states with East Darfur with Duai as its capital, South Darfur with Nyala as its capital, and Western Darfur with Geneina as its capital. Northern Darfur with El Fasher as the capital and Central Darfur with Zalingei as the capital (The Darfur Affairs Committee of Sudan Administration approved the administrative division on March 7, 2011. According to the result of the Darfur referendum conducted on April 23, 2016, it supported the continuation of the current administrative division). The total population of the five states is nearly 6 million, which accounts for $2 \%$ of the population of the Republic of Sudan before the secession. It is composed of over 80 tribes. Various tribes continue to make a mutual fight for natural resources. At the same time it is common to find frequent business transactions and interracial marriages.

The word "Dar" in "Darfur" is "دار" in Arabic, which is interpreted as"homeland". Therefore, it can be concluded that the Fur are the older aboriginal tribes in the area, including Fezara, Masalit, Rizaykat and Bakkara, etc. The Fur province and eastern Chad in the middle of the region constitute the major part of the Darfur tribe. Most of the farmers who live on farming and animal husbandry have settled here for a long time. Some of these families have evolved into nomads as a result of a large number of cattle. The Fezara tribe developed in the northern region of Darfur is a nomadic tribe mainly living on nomadic farming. The tribe is composed of the Dar Hamid, the
Zayadia, Beni Gerar, Baza'a, Ma'alia and so on. The Raizyat and Bakkara tribes in southern Darfur are famous for their bravery and warfare. When the Bakkara developed in Darfur, they were often plundered and excluded by other tribes due to their complacency and conservation. The tribe was not grown in an optimistic, so they allied with the Raizikt tribe.

In the southern region, there are the Mahamaid, Mahria, Nawaiba, Habaniya,Ta'ahisha, BeniHelba, Beni Khuzam. In addition, the Jaalin tribe is also one of the tribes that exerts a profound influence on Darfur. The original Jaalins live near Atbara in northern Sudan who make a living by business trade, agriculture, and animal husbandry. Other Jaaríns, including the Bedayria and Shaikia, have gradually penetrated into the Darfur region. They have been engaged in small-scale business exchanges with local blacks such as the Fur for a long time. With the business exchanges prospering, it promotes the occurrence of interracial marriages. Hence, it is easy to lead to a rough lineage of the Jaalin tribe, and the unorthordox descendants of the tribe. Some of them even live in Darfur forever.

\section{Early Internal Conflicts-Competition for Survival Resources}

In terms of Darfur in the pre-colonial period, it is not difficult to find that obvious suspicions and fierce disputes have existed in the tribes at that time. As the Christianity spread continuously, Kushi, the first dynasty of Sudan was conquered and perished, and three Christian kingdoms were subsequently established there. The people of all tribes in Darfur began to study what Christian doctrine and Christian civilization are. The majorities of Fur tribe and 
other black tribes make a living from farming and animal husbandry, and a small fraction of them live on nomadic herding. It was recorded that the Fur strictly followed the traditional Hakura land law. According to the contrast of the land law, only the rich people have the right to inherit the primitive religion of the land, producing a gap between nomads and farmers. It will be the root cause for the incoming violent clashes among various tribes. In the $7^{\text {th }}$ century A.D, a great many Arabs invaded and further intruded into the Darfur Plains, in which a series of strict policies were carried out for the bad intention of Islamization. However, the indigenous people of Darfur struggled to resist their violent invasion on the premise that Christianity and African primitive religions are still the beliefs of lots of Fur people. Arab tribes, foreign ecological immigration tribes, are mostly nomads. During the period when Darfur was forcibly Arabized, the conflict between the Arab tribe and the Fur tribe was fierce and armed struggle continued to aggravate.

As far as the colonial era is concerned, the Mahdi Revolt led by Mohammed Ahmed Ibn Abdullah broke out incurred by the brutal rule exerted by the colonizers. The rebel army strove to defeat the British-Egyptian rulers with irresistible force. Almost all the territories of Sudan were liberated, including the Darfur Plains today. Considering that the Mahdi was entitled to enjoy the fame and honor among the tribes, after he passed away, the faction conflict in Darfur, especially between the Fur and Arabs, has become increasingly prominent. In the 1980s, severe droughts and famines occurred in the area, and various tribes were in chaos. In the mid-to-late 1990s, armed conflicts between the Arabs of Rezajcat and the Zagawa, and between the Arabs and the Masalites has the tendency to intensify.

Generally speaking, because the production method differs from each other and the provisions of the traditional land law are not fair, divergences within the various tribes in Darfur appeared. In the later period, as Arab nomads continued to seize resources, all tribes in Darfur were confronted with domestic turmoil and foreign aggression. As a result, they maintained natural resentment and hatred for the Arab Muslims who migrated from the Nile river bank. In Darfur, there have been long-standing internal and external conflicts and turmoils between ethnic groups for the plundering of agriculture and animal husbandry. However, these conflicts are mostly traditional resource competitions rather than ethnic identity. Most of them are skirmishes.

\section{Qualitative Change of Conflicts-Political, Economic Marginalization and Identity Crisis}

During the colonial period, the Anglo-Ethiopia Government spared no efforts to perform the policy of "indirect rule" in Sudan 's Darfur and southern Sudan. However, what matters was that the stability of the situation was highlighted and its political, economic, and cultural construction were ignored. It led to the situation of political and economic marginalization in the region. The "indirect rule" policy divides Sudanese residents into indigenous and non-indigenous tribes. Among them, the former are indigenous peoples, who regard tribal names as their identities, while the latter are latecomers without citizenship. It accelerated the theory of racial differences in the region and caused a serious identity crisis.

Despite that Sudan was beyond the control of the Anglo-Ethiopia government, Darfur was still marginalized. The Sudanese government tended to assign Arabs to preside over important positions. In contrast, the Fur and the blacks were at a disadvantage position in Darfur 's political ecosystem. By virtue of the advantageous positions, the Arabs implemented the Islamization policy in Darfur. All citizens were forced to abandon Christianity and primitive religious beliefs and convert to Islam. Consequently, the native black tribes in the region were subject to a crisis of faith. In addition, Arab officials placed a high priority for economic investment in the central region, but ignored Darfur 's economic development. They took a monopoly of Darfur 's exclusive economic source, the Southern Oil Field in Darfur, making the habitants of Darfur live on the edge of starvation;

Prior to the colonial period, various tribes in Darfur were in a dispersed state and conflicts broke out to compete for prevalence of resources. But long-term inter-tribal exchanges have contributed to the formation of an effective mechanism to coordinate the struggle for interests between tribes. Whether it was during the Anglo-Ethiopia period or after Sudan 's independence, a series of administration policies led to the disintegration of the traditional governance model of the tribe. Additionally, the sole source of economic resources was controlled, and the original beliefs and identities suffered. Status suffered the resistance.

\section{Conflict Spillover-Regional Conflicts in Sudan, Chad and Libya}

The neighboring nations which border the Sudanese Darfur Plains are Chad, Libya and the Central African Republic. The sensitive geographical location and complicated tribal composition of the Darfur Plains in Sudan have impelled the involvements in various disputes with neighboring countries.

The Darfur region of Sudan and Chad both has origins in ethnic composition and political contacts. Historically, the Kingdom of Wade in eastern Chad was once reigned and dominated by the Kingdom of Fur. In the meantime there are a large number of Zagava people living in Chad belonging to the same ethnic group as the Zagava people in Darfur. In terms of the issue of land boundaries, both sides also had controversy about it. The dispute was not solved until the colonial period. Similar to the situation in Sudan, the northern and southern parts of Chad faced long-term confrontation because of religious, political, ethnic, land, and resource issues. Following closely, a civil war broke out in 1965. It was normal that Darfur was inevitably 
involved in the war. With the permission of the Sudanese government, it has become an important rear base for Chad 's anti-government armed forces. The resentment between the two countries was accelerated.

The traditional and friendly bilateral relations between Sudan and Libya broke down when the President of the Sudan, Nimaili, signed the Addis Ababa Treaty with the black countries in the south. President Gaddafi in Lybya treated the black people as enemies in the Arab region and resented their religious beliefs and ruling regimes. He was a supporter of "Pan Arabism with the extreme "Greater Libya" ambition. He was desirable for Arabization of Egypt, Libya, Chad and Sudan in order to establish a unified regime under the leadership of Libya. The Addis Ababa Treaty had a direct hit on Gaddafi's political ambitions and Islamic beliefs, resulting in the breakdown of relationship between the two countries. Because the Darfur area is the hub, Gaddafi was casting a greedy eye on its position.

During the civil war in Chad, since the Kuni side had a very close link with Libya, it agreed to merge with Libya. The Chad-Lybya Merger Plan was drafted. In order to realize the "Greater Libya", President Gaddafi gave the huge upported on Gukuni, attacked Darfur, and interfered in the civil war in Chad. At the same time, the intention of suppressing Sudan was achieved. Darfur was also utilized by Sudan to meddle in the civil war in Chad. Finally, it was the major support force of its anti-government armed forces. Therefore, the confrontation between Arabs and black Africans in Darfur has been escalated into regional conflicts in Sudan, Chad and Libya. As a result, the ethnic, racial and ethnic boundaries of the region became more distinctive. Meanwhile, with the expansion in this process, a large number of modern weapons and equipment were introduced to the Darfur region, which facilitated the aggravation of violence.

\section{Outbreak of Darfur Crisis and Its Internationalization-Active Humanitarian Assistance}

In 1999, anti-government armed forces, dominated by the black people of the Masaryt tribe, fought bravely against the repression of the Sudan government. The Sudan government built the "Janjaweed" and carried out savage act such as the Holocaust against blacks. Such terrible act aroused the international community's condemnation and attention. In 2002, two anti-government armed forces, the anti-government armed forces from Sultan Liberation Movement and the Justice and Equality Movement, were established one after another to combat against the Arab militia and the Sudanese government. In 2003, due to the initial victory of the Sultan Liberation Movement, many other small anti-government armed forces began to appear in the Western Darfur region. The terrorist forces act recklessly, and the regionalization crisis with Libya and Chad was further exacerbated. According to statistics, as of the end of 2004, the total number of people affected by the conflict in Darfur was 2.27 million, and the number of refugees in Darfur totals 1.65 million.

China's government expresses the clear attitude on the Darfur issue of Sultan. China respects the sovereignty and territorial integrity of Sudan. China will show active support and the necessary assistance to help Sudan rebuild and recover its economy. At the same time, China will provide humanitarian material assistance, and assign multiple peacekeeping troops to Sudan. However, it is stated that China will not interfere in the internal affairs of other nations and promote the just resolution of the Darfur crisis. China has made indelible and remarkable contributions to helping the Sudanese government in peacekeeping and development. The United States claimed that the Darfur issue shall be resolved within the framework of the United Nations. Britain, France, Germany and other Western allies shall be organized to impose political and economic sanctions on the Sudanese government, while actively providing humanitarian assistance. Under such background, President George W. Bush implemented the measures above driven by the pressure from many American civil organizations in order to win more votes in the elections and curb China 's development in Sudan in terms of oil cooperation. The AU's reform and poverty strategies have also played a crucial part in dealing with the Darfur political crisis. In the later period, the United Nations began to gradually take over from the AU and assumed the task of peacekeeping in Darfur. The UN is gradually changing from serving as an auxiliary role to a leading role. The UN Security Council unanimously approved a resolution unanimously on October 31, 2019 that the terms of office of the United Nations and the African Union Mission in Darfur (UNAMIDA) in Sudan was extended for one year until October 31, 2020.

\section{Conclusion}

The Darfur crisis is the final product of the escalation of internal conflicts of different tribes into national political and economic conflicts, and then the "internal conflicts" evolving into international conflicts as well as the excess interference in domestic conflicts of foreign forces. The stability of the international system is destroyed and the peace and development of the relevant countries are in a danger. Various nations and international organizations have played increasingly vital roles in the process of dealing with the Darfur crisis. However, the Darfur crisis is still evolving. The secession of South Sudan which occurred in July 9, 2011 has caused a demonstration effect in the Darfur region. The anti-government armed forces in the region obviously intended to establish an independent state. To prevent Darfur from becoming another South Sudan, economic investment, political management, and security supervision of Darfur must be strengthened. Furthermore, the major countries or international groups around the world should provide assistance and mediation without any hesitation. 


\section{ACKNOWLEDGMENT}

This work was supported by Innovative School Project in Higher Education of Guangdong, China (GWTP-FT-2015-15), and the Institute for Oriental Studies of Guangdong University of Foreign Studies.

\section{REFERENCES}

[1] Jiang H. (2007) The Historical Origin of the Darfur Issue, West Asia and Africa., 09: 22-28.

[2] Liu Z., Fan P. (2015) Summary and Reflections on China's Diplomatic Response to the Darfur Issue in Sudan, International Review., 05: 16-29.

[3] Liu H. (2011) Darfur: The Continuation of Sudan's Civil War, World Ethno-National Studies., 02: 23-29.

[4] Liang J. (2019) Identity Politics: The Historical Reasons and Impacts of Sudan's Tribes to Achieve Dominance, Arab World Studies., 02: 34-48.
[5] Adebajo, A. (2011) UN Peacekeeping in Africa: From the Suez Crisis to the Sudan Conflicts. Lynne Rienner Publishers, Boulder.

[6] Andrew, S (2012) Nations, Sudan, South South Sudan and Darfur. Oxford University Press, Oxford.

[7] Liu H., Li X. (2008) Research on the Darfur Issue from a Global Perspective. World Knowledge Press, Beijing.

[8] Liu H., Jiang H. (2008) Sudan. Social Sciences Academic Press(China), Beijing.

[9] Liang J. (2017) The Research of Tribal Society in Suan, Doctor Degree Dissertation, Northwest University.

[10] Peng Y. (2012) Original and Development of Darfur Issue, Master Degree Dissertation, East China Normal University.

[11] Xinhua Net, (2020) Security Council Extends Mandate of United Nations Mission in Western Sahara. http://www.xinhuanet.com/2020-03/13/c_1125704373.h tm 